\title{
JAG1 wt Allele
}

National Cancer Institute

\section{Source}

National Cancer Institute. AAG1 wt Allele. NCI Thesaurus. Code C75614.

Human JAG1 wild-type allele is located within 20p12.1-p11.23 and is approximately $36 \mathrm{~kb}$ in length. This allele, which encodes protein jagged-1, may play a role in the progression of hematopoiesis. Mutation of the gene is associated with Alagille syndrome type 1 and tetralogy of Fallot. 